Krasinsky Vladislav

Doctor of Law, member of the expert group

on international anti-extremist cooperation

with the Russian Ministry of Foreign Affairs

\title{
ON THE LEGAL POSITIONS OF THE EUROPEAN COURT OF HUMAN RIGHTS AND THE CONSTITUTIONAL COURT OF THE RUSSIAN FEDERATION ON RESTRICTIONS ON VOTING RIGHTS BECAUSE OF CRIMIAL RECORD
}

Abstract: in the article deals with the case-law of the European Court of human rights on the protection of the electoral rights of convicts, analyzes the approach of the Constitutional Court regarding criteria for eligibility and the right of prisoners to vote.

Keywords: Constitutional Court; European Court of Human Rights; limitation of the voting rights; disfranchisement; protection of the electoral rights of the convicts; anti-crime policy.

Krasinsky V.V. On the legal position of the European Court of Human Rights and the Constitutional Court of the Russian Federation relating to the limitation of voting rights because of criminal record // Modern Law. 2014. № 2. p. $34-41$

According to Part 3 of Article 32 of the Constitution citizens found incompetent by a court or kept in places of imprisonment upon ${ }^{1}$ conviction do not have active and passive suffrage.

In accordance with paragraph 3.2 of Article 4 of the Federal Law of June 12, 2002 № 67-FZ

"Do not have the right to be elected citizens of the Russian Federation who are:

${ }^{1}$ Currently, in the Russian Federation are deprived of voting rights 734300 people are serving time in prison upon conviction / on the Rights of the European Court's judgment of man from July 4, 2013 in the case of "Anchugov and Gladkov against Russia." 
a) condemned ever to imprisonment for committing grave and (or) a particularly serious crime, except in cases where, in accordance with the new criminal law, these acts are not recognized as a serious or especially serious crimes;

b) convicted of extremist crimes under the Criminal Code of Russian Federation, and having on the day of voting in the elections and unwithdrawn outstanding conviction for such offenses;

c) subjected to administrative punishment for propaganda and public demonstration of Nazi or similar extremist attributes and symbols, for the production and distribution of extremist materials, if election vote will take place before the end of the period during which a person is considered to be subject to administrative punishment;

g) or in respect of which came into force a court decision established that calls for extremist activity, justification or excuse of extremism, if such violations or acts committed prior to the day of voting in the elections for a term of the powers of state authority or local self-government, which are assigned to the elections, or official to be elected who will appoint the election."

These limits are imposed by the legislator in order to protect the public power institutions of criminalization. Electoral practice of elections at various levels confirms the validity of these restrictions.

Materials of the CEC of Russia show the regular participation of criminals in election campaigns and the increasing political activity of this category of citizens.

Increased activity of organized criminal organizations (communities), associated with attempts to be elected to bodies of state power and local selfgovernment, due to the interest of criminal organizations in a constant build-up of their income, the direct dependence of the formal and informal economic activities on the political situation in the Russian Federation, the desire of managers and participants criminal structures to ensure personal safety. For representatives of 
criminality election to public office and obtaining parliamentary mandate are presented solely significant.

Firstly, the fact of granting bandits of authority legalizes their criminal past and casts doubt on the connection with criminal societies (organizations).

Secondly, the election for public office or representative authority allows to acquire parliamentary immunity and rely on the special procedure in criminal cases, a defendant who may be a candidate.

Thirdly, the replacement of elected public office and membership of the bodies of the people's representatives give the appearance of bandits implementing powers in the name of and on behalf of the people.

Fourthly, official activation of material, financial, informational, legal and other resources of the state significantly extends the scope and power of influence of criminal societies (organizations) on social processes in the country and abroad.

Taking into account the increasing role of political parties in the electoral process, the most important task of criminal intelligence and counterintelligence was to establish control of organized criminal groups over the leading political parties (regional branches of political parties) and promotion of their representatives in the bodies of state power, local self-government and election commissions with party structures. In this regard, significantly increased the number of individuals associated with criminal environment in the party lists of candidates in the elections.

Analysis of the biographical data of candidates nominated by political parties that participated in the elections of deputies of the State Duma of the Federal Assembly of the Russian Federation of the fifth and sixth convocations, elections to bodies of state power of subjects of the Russian Federation and local government administrative centers of the Russian Federation September 8, 2013, information about unwithdrawn and outstanding conviction, about prosecute, on the election in respect of some of the nominees' measures of restraint in the form 
of detention, grounds for termination of the criminal prosecution of such persons, points the following ${ }^{1}$ circumstances:

- in the nominated and registered lists of all political parties that participated in the elections there were candidates to prosecute;

- among those with cancellation of conviction, the elections were put forward and the deputies of the State Duma of the Federal Assembly of the Russian Federation have been registered, members of legislative bodies of the Russian Federation, representative bodies of municipalities, chairmen of regional and local branches of parties, members of the federal and regional governing bodies of political parties;

- some candidates were convicted of crimes jointly, individuals were repeated criminal record, including the Serious formulations;

- in respect of a number of candidates to conduct a preliminary investigation and was elected a preventive measure in the form of detention;

- individual candidates were in the federal wanted list.

It should be stated that, despite the measures by election commissions and law enforcement measures, part of the citizens, to prosecute and have repaid previous convictions, was elected to the State Duma of the Federal Assembly of the Russian Federation, the legislative bodies of the Russian Federation, representative bodies of municipal formations.

Numerous facts of nomination and registration of candidates with criminal records were recorded during the elections to bodies of state power of subjects of the Russian Federation and local government administrative centers of the Russian Federation September 8, 2013

\footnotetext{
${ }^{1}$ A person convicted of offense is considered to be judged from the date of a court verdict in force until maturity or overturned.

2 Official statistics of election commissions at odds with those of law enforcement and intelligence agencies. This is due to the fact that the electoral commission analyzed the participation of persons with criminal records in electoral campaigns only option of having a criminal record for committing grave and (or) very serious crimes, while for information and reference records of the law enforcement bodies and special services of recorded data on criminal connections, the participation of citizens in the activities of criminal organizations (communities), about the procedural and investigative actions carried out against citizens of bodies of inquiry and investigation, as well as other operational-relevant information.
} 
The largest number of registered candidates, representing the interests of criminal organizations, it was noted in the elections of deputies of the State Assembly - Kurultai of the Republic of Bashkortostan - 1311 previous convictions candidates ran in the elections of deputies of the Legislative Assembly of the Trans-Baikal Territory and the election of deputies of the Legislative Assembly of the Vladimir region. 10 previous convictions of candidates to participate in elections of people's deputies of the Republic of Sakha, 8 - on elections of deputies to the People's Khural of the Republic of Buryatia, 7 - in the elections to the Legislative Assembly of the Rostov region.

The maximum number of representatives of the underworld in the municipal elections September 8, 2013 was registered in the lists of candidates in the Yekaterinburg City Duma - 7 people - and the Volgograd City Duma - 5 people.

The processes of criminalization of government and management require an adequate response from the state and civil society institutions, the implementation of a coherent anti-crime policy.

It appears that the main directions of countering the criminalization of public authorities in the Russian Federation should be built taking into account the existing international legal standards and international experience.

Proportionality, the admissibility and legitimacy of the establishment of a number of states limits the passive electoral rights of citizens has been discussed repeatedly in the jurisprudence of the European Court of Human Rights.

Article 25 of the International Covenant on Civil and Political Rights allows the introduction of reasonable restrictions on the right and opportunity of every citizen to be elected in the elections. As noted in the Court's rulings of the Human Rights Affairs' Mathieu-Mohin and Clerfayt v. Belgium"," Doyle v. the United Kingdom ", a person's right to stand for election is not ${ }^{1}$ absolute. Since Article 3 of the Protocol number 1 for the Protection of Human Rights and Fundamental

\footnotetext{
${ }^{1}$ Decision of the European Court of Human Rights on 2 March 1987 in the case of "Mathieu-Mohin and Clerfayt v. Belgium" // The European Court of Human Rights. Selected solutions: in 2 v M .: Norma, 2000; Decision of the European Court of Human Rights on 6 February 2007 in the case "Doyle v. the United Kingdom" // Bulletin of the European Court of Human Rights. Russian edition. 2007. № 8.
} 
Freedoms, recognizing this right does not specify it, much less give him the legal definition, there is an opportunity for the introduction of the so-called implicit or implied restrictions (judgment in the case "Mathieu-Mohin and Clerfayt v. Belgium"); States are free enough within its constitutional order to establish the status of parliamentarians, including the eligibility criteria (judgment in the case "Gitonas and others v. Greece", "Podkolzina v. Latvia", "Doyle v. the United Kingdom"). These criteria vary depending on the historical and political characteristics of each country.

In many foreign countries, persons serving sentences in prison under the sentence of the court is limited to the electoral law, or lack of ${ }^{1}$ it. In Austria, Belgium, France, Germany, Greece, Italy, Luxembourg, Malta, Netherlands, Norway, Poland, Romania and Turkey, there are limitations of the electoral rights of prisoners. In Armenia, Azerbaijan, Bulgaria, Estonia, Georgia, Ireland, Latvia, Liechtenstein, Moldova, the Russian Federation, Slovakia and the United Kingdom are deprived of voting rights.

In accordance with $\S 45$ of the Criminal Code of Germany deprivation of passive suffrage carried out for a period of 2 to 5 years. $\S 22$ Sec. 2 of the Regulation on the procedure for elections to the National Council of Austria (Nationalratswahlordnung 1992) provides for the deprivation of the convicted suffrage for $6^{2}$ months. In China, political (including election) rights for life deprived perpetrators of counter-revolutionary crimes and sentenced to the death penalty and life ${ }^{3}$ imprisonment.

According to the scope of the deprivation of the right to vote may apply to the election in a particular constituency (local deprivation) or to all types of elections throughout the state (the universal deprivation of rights). So, the person who committed corruption offenses in the UK electoral law (fraud, undue pressure

${ }^{1}$ Duksin PA Disenfranchisement of persons found incompetent by a court, and persons held in custody under a court sentence: fairness and appropriateness / Collection of competitive activities in the field of electoral law, electoral process and legislation on the referendum carried out by students and graduate students of higher legal education of the Russian Federation, institutions in 2004-2005. M .: RTSOIT, 2005, pp 125-138.

2 Bundesgesetz BGB1. Nr. 47/1992; BGB1. I Nr. 28/2007.

${ }^{3}$ Foreign suffrage: Textbook. M .: Norma, 2003. P. 168. 
on voters, exceeding the size limits of election expenses, bribery, falsification of nomination papers), is deprived of passive suffrage for 10 years throughout the country. For illegal practices (violation of various legal requirements of authorized representatives, the use of premises, advertising, coverage of the election campaign, voting more than once, voting, despite the loss of voting rights, etc.) To the offender apply deprivation of passive suffrage for 5 years in the territory a particular ${ }^{1}$ constituency.

On the content of seizures legal disenfranchisement can be classified on the deprivation of active suffrage and passive suffrage deprivation. Decision of the State Tribunal of the Republic of Poland a person who commits an offense involving a violation of the Constitution or laws, can be deprived of both active and passive suffrage in the election of all kinds (p.1 Art. 23 of the Law "On State tribunal" dated March 26, 1982²). In Canada, passive suffrage deprived persons serving sentences in places of deprivation of liberty for more than two $^{3}$ years.

Liberalization of penal policy in the European Union countries has led to a change in the legal position of organs of constitutional justice on the protection of the electoral rights of convicted persons. So, October 6, 2005, the Grand Chamber of the European Court of Human Rights issued a final judgment in the case "Hirst v United Kingdom» complaint № ${ }^{4} 74025 / 01$.The applicant, John Hirst, who was sentenced to life imprisonment for murder, appealed against the provisions of Art. 3 Representation of the People Act of 1983 on the prohibition of participation in the elections to the Parliament or local authority. The Court acknowledged the discrepancy Article 3 of the Representation of the People Act of Protocol № 1 of the Convention on Human Rights. According to the Court, the ban on prisoners

${ }^{1}$ In accordance with the Representation of the People Act 1983 (the Representation of the People Act 1983 ) in the UK electoral law all offenses are divided into 2 types - corruption and illegal practices (corrupt or illegal practices), which leads to restriction of the offender passive suffrage. A similar classification of offenses in the sphere of electoral law is adopted in Canada. See Foreign suffrage:. Textbook. M .: Norma, 2003. P. 86. 370.

2 The modern electoral systems. Vol. 1: United Kingdom, Canada, Mexico, Poland. Norm M .: 2006 p.

3 Ibid. p. 207.

4 The European Court of Human Rights judgment of 6 October 2005 in the case of Hirst v. The United Kingdom (complaint No. 74025/01) // Bulletin of the European Court of Human Rights. Russian edition. 2006. № 4. 
participating in elections should apply to all convicted persons, in addition, this restriction should be applied depending on the length of the sentence imposed and the gravity of the offense. The Court gave the United Kingdom the right to choose the method of providing electoral rights of ${ }^{1}$ prisoners.

Formulated by the European Court of the legal position in the case of "Hirst v. United Kingdom» that the automatic and undifferentiated disfranchisement of a group of persons, regardless of their sentence, the nature or gravity of the offense and the personal circumstances is incompatible with Art. 3 of Protocol № 1 of the Convention was later confirmed in its judgment of 8 April 2010 in the case of "Frodl v. Austria" and its Resolution of 22 May 2012 on the case "Scoppola v. Italy," Decree of 4 July 2013 on the case "Anchugov and Gladkov v. Russia."

In its judgment of 8 April 2010 in the case of "Frodl v. Austria", the Court recalled that "disenfranchisement may be provided only for criminals serving long terms of imprisonment; between the facts underlying the conviction and sanction of deprivation of electoral rights must be a direct link; and such a measure should preferably not be used by operation of law, and by the decision of the judge on the results of the ${ }^{2}$ trial."

In the judgment of 22 May 2012 on the case "Skoppola against Italy," the Court stated that "the measures to restrict the electoral rights of prisoners are not the same in different national legal systems. States Parties may include the proportionality of measures to restrict the electoral rights of prisoners to the courts or to include in the legislation provisions defining the circumstances under which such a measure is applied. In the latter case, the legislator must weigh the competing interests in order to avoid any automatic and indiscriminate ${ }^{3}$ restriction."

\footnotetext{
${ }^{1}$ In states where prisoners have the right to vote (Albania, Bosnia and Herzegovina, Cyprus, Croatia, Czech Republic, Denmark, Finland, the former Yugoslav Republic of Macedonia, Iceland, Lithuania, Portugal, Slovenia, Spain, Sweden, Switzerland and Ukraine), they realize their electoral right by voting by mail, by proxy and other means provided by law.

2 European Court of Human Rights judgment of 8 April 2010 in the case of Frodl v. Austria (complaint No. 20201/04) // Information Bulletin on the Case-Law of the European Court of Human Rights. 2010, No. 129.

3 Decision of the European Court of Human Rights on May 22, 2012 in the case of Scoppola v. Italy (complaint No. 74025/01) // Bulletin of the European Court of Human Rights. Russian edition. 2012, No. 11.
} 
The most serious political and legal consequences for the Russian Federation has the European Court of Human Rights on 4 July 2013 in the case of "Anchugov and Gladkov v. Russia." In that case the Strasbourg Court with reference to the legal position in the case of "Hirst v. the United Kingdom" has recognized that Part 3 of Article 32 of the Constitution violates Art. 3 of Protocol № 1 to the European Convention, which guarantees the right of free elections. In response to the arguments of the Government that this case is distinguishable from "Hirst v. the United Kingdom", as Russian ban prisoners to participate in elections is set by the Constitution, adopted by popular vote, rather than a "normal law", the Court pointed out, that the Convention applies to all regulations and measures relating to the jurisdiction of the national authorities, which are realized through the Constitution.

The Strasbourg court ruled that the authorities had failed to provide evidence that in the course of extensive public discussion draft of the Constitution considered the question of the proportionality of the contested restrictions in the public interest. While litigating the position of the Russian side that the amendment of Art. 32 of the Constitution of the Russian Federation is a complex procedure (the inability to review by the Federal Assembly, the need to support a proposal for the revision of $3 / 5$ of the votes of all the members of the Federation Council and the State Duma, the convening of the Constitutional Assembly), the European Court of Human Rights pointed out that the way to remedy the violation found It is at the discretion of the respondent state, while being under the supervision of the Council of Europe Committee of ${ }^{1}$ Ministers. And the government may well have recourse for this purpose to one or another political process or interpret the Constitution accordingly.

It seems that commented on the Human Rights of the European Court's judgment calls into question the principle of the rule of the Constitution (Part 1 of Article 15 of the Constitution), and thereby violates the sovereignty of our state.

${ }^{1}$ The composition, procedure for the formation and activities of the Constitutional Assembly shall be regulated by the Federal Constitutional Law "On the Constitutional Assembly of the Russian Federation", which has not been adopted to date. 
The opinion of a few tens of judges to the European Court negates the legal expression of the will of millions of Russian citizens on the state and public life, expressed in the Constitution. It is the multinational people of Russia, rather than the Strasbourg Court, accepting the popular vote in the 1993 Constitution of the Russian Federation, has identified the characteristics and limits of state authority, the conditions and procedures for the implementation of the rights of citizens to participate in managing the affairs of society and state mechanisms for the protection of the government.

The Russian Constitution does not allow any other bearer of sovereignty and power sources other than the people of the Russian Federation and Article 79 of the Constitution does not provide for the assignment or the possibility of division of sovereignty of the Russian Federation with the international community.

October 10, 2013 the position of the European Court of suffrage restrictions in connection with the problem of the presence of a criminal record was considered by the Constitutional Court of the Russian Federation in deciding the case "On the constitutionality of subparagraph" a "of paragraph 3.2 of Article 4 of the Federal Law" On Basic Guarantees of Electoral Rights and the right to participate in the referendum citizens of the Russian Federation", the first part of article 10 and paragraph 6 of article 86 of the Criminal Code in connection with complaints G.B. Egorova citizens A.L. Kazakova, I.Yu. Kravtsova, A.V. Kupriyanov, A.S. Latypova and V.Y. Sinkova" ${ }^{1}$.

The problem of protecting the electoral rights of convicts considered by the Constitutional Court in connection with the detection system entities and publiclaw consequences of a criminal record. As pointed out by the Constitutional Court in its judgment of 19 March 2003 № 3-P "On the case on the constitutionality of provisions of the Criminal Code of the Russian Federation governing the legal consequences of criminal convictions, repeatedly and recidivism, as well as items 1-8 decision of the State Duma of the Federal Assembly Russian Federation dated

\footnotetext{
${ }^{1}$ Decree of the Constitutional Court of the Russian Federation of October 10, 2013 No. 20-P // Ros. gas. 2013. October 23rd.
} 
May 26, 2000 "on amnesty in connection with the 55th anniversary of the Victory in the Great Patriotic War of 1941-1945" on the request of the Ostankino intermunicipal (district) court of Moscow complaints of a number of citizens", "criminal record is a legal condition of a person due to the fact of conviction and purpose to him upon conviction a sentence for ${ }^{1}$ crime."

State criminal records are urgent. A conviction occurs when a conviction for an offense from the date of a judgment of conviction enters into force, and terminated at the time of redemption or withdrawal.

Not always the removal or cancellation of conviction cancels its legal consequences. The presence of criminal convictions poses special public law relationship with the state.

Legal consequences of conviction allows strict requirements for the possible criminal background of applicants for positions of judges, prosecutors, police officers, security officers, as well as educators, education, recreation, health care, social protection of minors, youth sport, culture and art.

According to paragraph 1 of Article 4 of the Law of the Russian Federation "On the Status of Judges in the Russian Federation", paragraph 2 of Article 40.1 of the RF Law "On the Russian Federation Prosecutor's Office", paragraphs 2 and 3 of Part 1 of Article 29 of the Federal Law "On Police", subparagraph 4 of paragraph 5 article 18 of the Federal law "On state protection", paragraph "c" of part 3 of article 16 of the Federal law "On Federal security service", paragraph 2 of part 4 of article 16 of the Federal law "On the Investigative Committee of Russia" citizen with a criminal record (including withdrawn or maturity), and in respect of which the prosecution terminated by the expiration of the period of limitation, in connection with the reconciliation of the parties, as a result of an amnesty or in connection with active repentance will never be able to enter the service or work in the prosecutor's office, police, organs of the state guard, the federal security service, the investigating authorities may not be appointed as a judge.

These requirements would seem logical.

\footnotetext{
1 Ros. Gas. 2003. 2 April.
} 
No one raises objections ban on labor activity in the field of education, education, juvenile development, the organization of their rest and recovery, health care, social protection and social services, in the field of youth sport, culture and art with the participation of minors in relation to persons who have or had a criminal record, have been or are prosecuted for crimes against life and health, freedom, honor and dignity, inviolability and sexual Tin individual liberty against the family and minors, public health or public morality, the constitutional order and security. In accordance with Article 351.1 of the Labor Code of the Russian Federation for all the above persons there is a certificate of no criminal record is a mandatory document for the conclusion of an employment contract.

In judicial practice, criminal record associated with the fact of serving) punishment. Accordingly h. 2 tbsp. 86 of the Criminal Code a person released from punishment, is considered criminal record. In Sec. 5 of the Resolution of the Plenum of the Supreme Court on March 18, 1970 number 4 (as amended and additional, amended Resolution of the Plenum of the Supreme Court on September 21, 1977 № 11;Z On April 26, 1984 №7)" The calculus maturity conviction "stated that" at decision conviction without assigning penalty, as well as the release convict from punishment force amnesty or due to expiration of limitation period perpetrator as not serving a sentence is recognized as not having a criminal record, regardless of duration of preliminary ${ }^{1}$ conclusion."

Resolution of the Constitutional Court on October 10, 2013 № 20-P affirmed the constitutionality of the restriction of passive suffrage for those convicted for grave and especially grave crimes, "democracy requires legal reliably protect her from abuse and criminalization of public authority, the legitimacy of which is largely It is based on the trust of society. Based on this, a ban from holding public office for persons committing grave and especially grave crimes,

\footnotetext{
1 Resolution of the Plenum of the Supreme Court of the USSR of March 18, 1970 No. 4 "On the calculation of the period of repayment of criminal record" / / Sat. Decisions of the Plenum of the Supreme Court of the USSR 1924-1977. Part 2. Moscow: Izvestiya, 1978; Resolution of the Plenum of the Supreme Court of the USSR of September 21, 1977 No. 11 "On amending and supplementing the Resolution of the Plenum of the Supreme Court of the USSR of March 18, 1970 No. 4" On Calculating the Term of Repayment of Criminal Records. " [The text has not been published.]
} 
pursuing a constitutionally significant goals. ... The restriction of passive suffrage introduced by the federal legislator as a special constitutional and legal disqualifying obstacles for holding elective public office, coupled with the increased reputational requirements for holders of public (political) power, which is due to their direct participation in the adoption of legal acts (regulations and individual) and responsibility, which is associated with the exercise of their 1powers."

At the same time, the indefinite and undifferentiated restriction of passive voting rights in respect of Russian citizens, sentenced to imprisonment for committing grave and (or) a particularly serious crime, which is not a criminal penalty, is recognized by the Constitutional Court as not relevant to Articles 3 (parts 2 and 3), 15 (part 4) 17 (part 3), 19 (part 1 and 2), 32 (parts 1, 2 and 3) and 55 (sections 2 and 3 ) of the ${ }^{2}$ Constitution. As decided by the Constitutional Court, in its judgment should specify the duration of the constitutional and legal obstacles to employment disqualifying convicted persons elected public office after serving their sentences.

According to the Constitutional Court of the Russian Federation, the terms imposed by federal law restrictions of passive suffrage, as a general rule, should be set accordingly differentiation periods criminal record, provided the Criminal ${ }^{3}$ Code. In exceptional cases, for certain serious and heinous crime, based on the increased degree of danger to society, a federal law may be limitations of passive suffrage and for a longer period in accordance with constitutional criteria of proportionality and necessity.

The Constitutional Court also ruled that the federal legislator to establish procedural safeguards to ensure the ability to recover the passive electoral rights of

\footnotetext{
${ }^{1}$ Ros. gas. 2013. October 23rd.

2 Ros. gas. 2013. October 23rd.

3 According to the bill submitted to the State Duma after the adoption by the Constitutional Court of the Russian Federation of Resolution No. 20-P of October 10, 2013, convicted of ever having been deprived of liberty for committing serious crimes, except in cases where, in accordance with the new criminal law, these acts are not recognized as serious crimes, they will not be able to run for 10 years from the date of the removal or repayment of convictions, and those who have ever been sentenced to deprivation of liberty for committing particularly serious crimes - within 15 years from the date of removal repayment of conviction.
} 
citizens, whose criminal record is removed or extinguished, in the case of adoption of the new criminal law, according to which of the acts are no longer recognized as serious or very serious offense.

The analysis of the constitutional-legal doctrine leads to the following conclusions:

1. The legal position of the judiciary indicate the further unification of the approaches of the European and Russian bodies of constitutional justice in regard to the eligibility criteria and the active suffrage, necessitating changes in the national legislation of the Russian Federation. Judgments of the European Court of Human Rights on 6 October 2005 in the case of "Hirst v. the United Kingdom," from April 8, 2010 on the case "Frodl v. Austria," and on May 22, 2012 in the case "Scoppola v. Italy" from July 4, 2013 in the case of "Anchugov and Gladkov v. Russia", Decision of the Constitutional Court on October 10, 2013 № 20-P on the case" on checking the constitutionality of subparagraph "a" of paragraph 3.2 of article 4 of the Federal law "on basic guarantees of electoral rights and the right to participate in referendum i.e. citizens of the Russian Federation ", the first part of Article 10 and paragraph 6 of Article 86 of the Criminal Code in connection with complaints of citizens G.B. Egorova, A.L. Kazakova, I.Yu. Kravtsova, A.V. Kupriyanov, A.S Latypova and V.Y. Sinkova" which implies that the passive suffrage shall be given: persons who conditional sentence imposed; exempt from punishment; amnestied and pardoned; persons to whom a court sentence is not sentenced to deprivation of the right to occupy certain ${ }^{1}$ positions.

2. Legislative regulation of the constitutional restrictions on the rights and freedoms of citizens aimed at bringing the timing constraints of the passive electoral rights of prisoners in accordance with the degree of public danger of crimes, type of punishment (imprisonment) and terms of convictions. Convicted of serious crimes to imprisonment are denied the right to run for 10 years from the

\footnotetext{
${ }^{1}$ According to Article 311 of the Code of Criminal Procedure of the Russian Federation, in the case of a conviction without a sentence; conviction with the appointment of punishment and with the release of his serving; conviction with the imposition of punishment not related to deprivation of liberty, or punishment in the form of deprivation of liberty, the defendant who is in custody, who is in custody, is immediately released in the courtroom.
} 
date of withdrawal or cancellation of conviction, and sentenced for especially grave crimes - for 15 years from the date of withdrawal or cancellation of conviction. Provided by the Constitutional Court in its decision of October 10, 2013 № 20-P possibility of limiting the right to be elected for longer periods it is advisable to distribute the following compounds provided by Articles 205 "terrorist act", 208 "organization of an illegal armed formation or participation in it," 209 "banditry" 210 "organization of a criminal community (criminal organization) or participation in it," Art. 211 "hijacking an aircraft or water transport or railway rolling stock" 275 "high treason", 277 "attempt against a state or public figure" 278 "violent seizure of power or forcible retention of power" 279 "armed rebellion" of the Criminal Code of the Russian Federation.

3. The implementation of international standards in the Russian legislation actualizes the significance of the judicial practice of assigning criminal penalties in the form of deprivation of the right to hold elective offices. Modernization of material and procedural norms in accordance with international standards will require from the organizers of elections a uniform practice of clarifying the severity of crimes, taking into account the period of validity of different versions of the criminal law.

4. The most serious political and legal consequences for the Russian Federation has for Human Rights the European Court on 4 July 2013 in the case of "Anchugov and Gladkov v. Russia," which challenged the supremacy of the Constitution and violated the sovereignty of the Russian Federation in terms of determining the characteristics and limits of state power, conditions and procedures for the implementation of the rights of citizens to participate in managing the affairs of society and the state. In this regard, in order to prevent further attempts to limit the sovereignty of the Russian Federation, undermining the principle of supremacy of the Constitution, the intervention of international organizations in our system of democracy is necessary to bring the Russian Federation ratified international treaties and obligations associated with them in accordance with the 
interests of protecting the constitutional system. With all due respect to the Strasbourg court constitution Russia must love, respect and stand firm.

Krasinsky Vladislav

Doctor of Law, member of the Public

Advisory Scientific and Methodological Council of the CEC of Russia 